\title{
EDITORIAL \\ Action on sickle cell retinopathy: the time is now
}

\author{
(c) The Author(s), under exclusive licence to The Royal College of Ophthalmologists 2021
}

Eye (2022) 36:1138-1139; https://doi.org/10.1038/s41433-021-01918-y

Despite sickle-cell disease being one of the commonest genetic disorders in the UK, with $\sim 14,000$ people affected [1], there is no clear guidance on sickle cell retinopathy screening or treatment and no clear picture of the current natural history and prevalence of retinopathy in the UK. Progress has been slow in developing effective systemic treatments with, until recently, hydroxycarbamide (hydroxyurea) being the only drug approved to treat sickle cell disease in the United Kingdom.

However, 3 new drugs have been approved by the US Food and Drug Administration [2] and one of these, crizanlizumab, has just been approved by NICE, heralding new hope for this much neglected disease [3]. In parallel, recent advances in ocular imaging, present a unique opportunity for the ophthalmic community to contribute to closing the knowledge gap that still exists in our understanding and management of sickle cell retinopathy and sickle cell disease.

Classified by Goldberg in 1971 [4], sickle cell retinopathy remains one of the most recognisable systemic disease associations in the field of retina. Natural history data largely comes from cohort studies from Jamaica in the 80 s and 90 s noting the higher prevalence of proliferative sickle retinopathy in people with SC genotype and a high incidence of spontaneous regression [5-7]. However, does this apply now? UK patients may be more genetically diverse, compared to those in Jamaica, and the treatment of sickle cell disease has changed since these early studies were conducted. Babies born in the UK are now screened for the sickle cell gene [8] and are actively managed, including starting hydroxycarbamide, which has greatly improved life expectancy and hopefully will improve on the previously reported natural history [9]. However, increasing age is an established risk factor for proliferative sickle retinopathy [5] and we may still see higher prevalence of advanced sickle retinopathy as the population ages. In addition, increased migration is bringing patients to the UK at different stages of the disease, some of whom may not already have a diagnosis of sickle cell disease on presentation.

Whilst proliferative sickle retinopathy can regress, we do not yet understand the factors that promote regression [5]. There is evidence from two randomised controlled trials conducted over 30 years ago that scatter laser photocoagulation leads to a modest reduction in the occurrence of vitreous haemorrhage and visual loss in eyes with proliferative retinopathy compared to observation but which laser technique and when to intervene remains uncertain [10]. Although the incidence of visual impairment due to sickle retinopathy has not been published in UK, case series from units in the UK serving populations with a high prevalence of sickle cell disease reflect ongoing occurrence of significant irreversible visual impairment following vitrectomy for eyes that progress to vitreous haemorrhage and retinal detachment (stage 4 and 5 proliferative sickle retinopathy) $[11,12]$. Anti-VEGF injections are being used by some clinicians to control neovascularisation [13]. Further trials on when to intervene and how are needed.
Studies have shown that ultra-widefield fundus photography (UWF-FP) more reliably detects sickle cell retinopathy than clinical examination or standard field fundus photography in adults and paediatric populations [14, 15]. Visual loss can also occur due to maculopathy, which was not included in the earlier disease classifications.

Optical coherence tomography (OCT) and OCT-angiography (OCT-A) imaging enable us to non-invasively observe the impact of sickle cell disease on the macular structure and vasculature. Studies have shown us that the prevalence of sickle maculopathy is much higher and occurs earlier than previously described [16]. Multiple structural OCT changes have been described in sickle maculopathy such as foveal splaying, inner and outer retinal thinning predominantly in the temporal region of the macular and choroidal thinning [17]. Fluorescein angiography (FA) remains the gold standard for staging and monitoring sickle cell retinopathy, with UWF-FA enabling visualisation of vascular features and leakage of sickle retinopathy lesions in the far periphery [18]. Positive correlations between macular thinning on OCT and ischaemic index on UWF-FA have been reported, suggesting a possible role for macular OCT in screening for proliferative sickle retinopathy [19]. OCT-A quantitative metrics have been demonstrated to precede macular thinning, supporting the hypothesis that thinning is as a result of accumulation of vaso-occlusive events at the level of the retinal capillaries [20]. Wide-field swept OCT-A may help advance its value.

There are no prospective studies evaluating the impact of current systemic treatments on the evolution of proliferative sickle retinopathy although it is logical to deduce systemic therapy that reduces vaso-occlusive events will positively impact on incidence and progression of sickle retinopathy. For instance, red cell exchange transfusion has been shown to stabilise rapidly progressive proliferative sickle retinopathy in a case report [21]. Hydroxycarbamide increases the production of $\mathrm{HbF}$ ( $\mathrm{HbF}$ does not sickle) and in one retrospective case series, children with $\mathrm{HbF}<15 \%$ had a 7.1 -fold higher odds of developing sickle retinopathy [22]. Mian et al. reported similarly positive effects of $\mathrm{HbF}$ levels over $15 \%$ in a retrospective crosssectional study of 300 adults with HbSS [23]. Hydroxycarbamide therapy has also been shown to be associated with reduced rates of retinal thinning on OCT [24].

We believe national sickle cell retinopathy screening guidelines mandating annual screening from age of 10 years with UWF-FP and OCT need to be considered. An associated, funded image database hub linked to the national haemoglobinopathy registry, would provide researchers with invaluable data to continue to unravel the evolution of sickle retinopathy, the influence of systemic parameters and therapies on progression of sickle cell retinopathy, as well as allowing researchers to understand whether ocular imaging parameters can predict systemic progression and complications reliably and be used to help guide haematologists in their use of the additional new treatments as they become available. Such progress is long overdue and much deserved. 
Christiana Dinah $\mathbb{D}^{1 凶}$, Brigit Greystoke ${ }^{2}$, Isabella Mueller $\mathbb{D D}^{2}$ and James Talks ${ }^{2}$

${ }^{1}$ London North West University Healthcare NHS Trust, Watford Road, Harrow, HA1 3UJ London, UK. ${ }^{2}$ Royal Victoria Infirmary, Newcastle Hospitals NHS Foundation Trust', Newcastle Upon Tyne, UK.

凶email: christiana.dinah@nhs.net

\section{REFERENCES}

1. Dormandy E, James J, Inusa B, Rees D. How many people have sickle cell disease in the UK? J Public Health (Oxf). 2018;40:e291-5. https://doi.org/10.1093/ pubmed/fdx172.

2. Salinas Cisneros G, Thein SL. Recent advances in the treatment of sickle cell disease. Front Physiol. 2020;11:435. https://doi.org/10.3389/fphys.2020.00435.

3. National Institute of Health and Care Excellence Technology appraisal guidance (TA743). Crizanlizumab for preventing sickle cell crises in sickle cell disease. 2021. https://www.nice.org.uk/guidance/ta743. Accessed 08/11/2021.

4. Goldberg MF. Classification and pathogenesis of proliferative sickle retinopathy. Am J Ophthalmol. 1971;71:649-65. https://doi.org/10.1016/0002-9394(71)90429-6.

5. Downes SM, Hambleton IR, Chuang EL, Lois N, Serjeant GR, Bird AC. Incidence and natural history of proliferative sickle cell retinopathy: observations from a cohort study. Ophthalmology. 2005;112:1869-75. https://doi.org/10.1016/j. ophtha.2005.05.026. Epub 2005 Sep 19.

6. Fox PD, Vessey SJ, Forshaw ML, Serjeant GR. Influence of genotype on the natural history of untreated proliferative sickle retinopathy-an angiographic study. $\mathrm{Br}$ Ophthalmol. 1991;75:229-31. https://doi.org/10.1136/bjo.75.4.229.

7. Talbot JF, Bird AC, Maude GH, Acheson RW, Moriarty BJ, Serjeant GR. Sickle cell retinopathy in Jamaican children: further observations from a cohort study. $\mathrm{Br} J$ Ophthalmol. 1988;72:727-32. https://doi.org/10.1136/bjo.72.10.727.

8. Streetly A, Clarke M, Downing M, Farrar L, Foo Y, Hall K, et al. Implementation of the newborn screening programme for sickle cell disease in England: results for 2003-2005. J Med Screen. 2008;15:9-13. https://doi.org/10.1258/jms.2008.007063.

9. Lobitz S, Telfer P, Cela E, Allaf B, Angastiniotis M, Backman Johansson C, et al. Newborn screening for sickle cell disease in Europe: recommendations from a Pan-European Consensus Conference. Br J Haematol. 2018;183:648-60. https:// doi.org/10.1111/bjh.15600. with the endorsement of EuroBloodNet, the European Reference Network in Rare Haematological Diseases. Epub 2018 Oct 18.

10. Myint KT, Sahoo S, Thein AW, Moe S, Ni H. Laser therapy for retinopathy in sickle cell disease. Cochrane Database Syst Rev. 2015;10:CD010790. https://doi.org/ 10.1002/14651858.CD010790.pub2.

11. Ho J, Grabowska A, Ugarte M, Muqit MM. A comparison of 23-gauge and 20gauge vitrectomy for proliferative sickle cell retinopathy-clinical outcomes and surgical management. Eye (Lond). 2018;32(Sep):1449-54. https://doi.org/10.1038/ s41433-018-0127-y. Epub 2018 May 22.

12. Williamson TH, Rajput R, Laidlaw DA, Mokete B. Vitreoretinal management of the complications of sickle cell retinopathy by observation or pars plana vitrectomy. Eye (Lond). 2009;23:1314-20. https://doi.org/10.1038/eye.2008.296. Epub 2008 Oct 3.

13. Mishra K, Bajaj R, Scott AW. Variable Practice Patterns for Management of Sickle Cell Retinopathy. Ophthalmol. Retina 2021;5:715-7. https://doi.org/10.1016/j. oret.2020.11.017. Epub 2020 Dec 7.

14. Alabduljalil T, Cheung CS, VandenHoven C, Mackeen LD, Kirby-Allen M, Kertes PJ, et al. Retinal ultra-wide-field colour imaging versus dilated fundus examination to screen for sickle cell retinopathy. Br J Ophthalmol. 2021;105:1121-6. https://doi. org/10.1136/bjophthalmol-2020-316779. Epub 2020 Aug 19.

15. Han IC, Zhang AY, Liu TYA, Linz MO, Scott AW. Utility of ultra-widefield retinal imaging for the staging and management of sickle cell retinopathy. Retina. 2019;39:836-43. https://doi.org/10.1097//AE.0000000000002057.
16. Leitão Guerra RL, Leitão Guerra CL, Bastos MG, de Oliveira AHP, Salles C. Sickle cell retinopathy: What we now understand using optical coherence tomography angiography. A systematic review. Blood Rev. 2019;35:32-42. https://doi.org/ 10.1016/j.blre.2019.03.001. Epub 2019 Mar 4.

17. Mathew R, Bafiq R, Ramu J, Pearce E, Richardson M, Drasar E, et al. Spectral domain optical coherence tomography in patients with sickle cell disease. $\mathrm{Br}$ Ophthalmol. 2015;99:967-72. https://doi.org/10.1136/bjophthalmol-2014305532. Epub 2015 Jan 16.

18. Cho M, Kiss S. Detection and monitoring of sickle cell retinopathy using ultra wide-field color photography and fluorescein angiography. Retina. 2011;31:738-47. https://doi.org/10.1097/IAE.0b013e3181f049ec.

19. Ghasemi Falavarjani K, Scott AW, Wang K, Han IC, Chen X, Klufas M. et al. Correlation of multimodal imaging in sickle cell retinopathy. Retina. 2016;36 Suppl 1 : S111-7. https://doi.org/10.1097/IAE.0000000000001230.

20. Ong SS, Linz MO, Li X, Liu TYA, Han IC, Scott AW. Retinal thickness and microvascular changes in children with sickle cell disease evaluated by optical coherence tomography (OCT) and OCT angiography. Am J Ophthalmol. 2020;209:88-98. https://doi.org/10.1016/j.ajo.2019.08.019. Epub 2019.

21. Khwarg SG, Feldman S, Ligh J, Straatsma BR. Exchange transfusion in sickling maculopathy. Retina 1985;5:227-9. https://doi.org/10.1097/00006982198500540-00007. Fall-Winter.

22. Estepp JH, Smeltzer MP, Wang WC, Hoehn ME, Hankins JS, Aygun B. Protection from sickle cell retinopathy is associated with elevated $\mathrm{HbF}$ levels and hydroxycarbamide use in children. Br J Haematol. 2013;161:402-5. https://doi.org/ 10.1111/bjh.12238. Epub 2013 Feb 6.

23. Mian UK, Tang J, Allende APM, Heo M, Bernstein N, Vattappally $L$, et al. Elevated fetal haemoglobin levels are associated with decreased incidence of retinopathy in adults with sickle cell disease. Br J Haematol. 2018;183:807-11. https://doi.org/ 10.1111/bjh.15617. Epub 2018 Nov 12.

24. Lim Jl, Niec M, Sun J, Cao D. Longitudinal assessment of retinal thinning in adults with and without sickle cell retinopathy using spectral-domain optical coherence tomography. JAMA Ophthalmol. 2021;139:330-7. https://doi.org/10.1001/ jamaophthalmol.2020.6525.

\section{AUTHOR CONTRIBUTIONS}

CD conceived the work, drafted and revised the work and approved final version, $B G$ contributed to draft, revised the work and approved final version, IM contributed to draft, revision and approved final version and JT conceived the work, contributed to draft and revised the work and approved the final version.

\section{COMPETING INTERESTS}

The authors declare no competing interests.

\section{ADDITIONAL INFORMATION}

Correspondence and requests for materials should be addressed to Christiana Dinah

Reprints and permission information is available at http://www.nature.com/reprints

Publisher's note Springer Nature remains neutral with regard to jurisdictional claims in published maps and institutional affiliations. 